\title{
The Scope of Federal Venue over Corporations in Multidistrict States
}

The establishment of the proper venue ${ }^{1}$ in civil actions ${ }^{2}$ generally requires the selection of a forum having some connection with either the claim or the parties to the litigation. This requirement reflects the policy that actions should be brought im geographically specified courts in order to lend a degree of certainty to the forum selection process and to prevent unnecessary inconvenience to the parties involved in the litigation. ${ }^{3}$ This Comment considers an important problem in the interpretation of federal venue law: whether a business incorporated or hicensed to do busmess ${ }^{4} \mathrm{~m}$ a state that has multiple federal judicial districts ${ }^{5}$ can be sued in any federal district in that state.

If a corporate defendant does business in only one of the federal judicial districts in a multidistrict state, it will probably object if a plaintiff attempts to establish venue in some other district within that state, particularly if that district is geographically remote from the cor-

1. "Venue" refers to "the locality of a lawsuit-the place where judicial authority may be exercised." "Jurisdiction" refers to the source of the authority of the court. Neirbo Co. v. Bethlelem Shipbuilding Corp., 308 U.S. 165, 167-68 (1939). Venue is a privilege that may be waived by a party, while jurisdiction is a power granted by constitution or statute that no party has the authority to confer. Id.

2. The selection of the proper venue in criminal actions las constitutional implications. U.S. ConsT. annend. VI (trial must be lield in state and district where the crime committed). In contrast, there is no constitutional right to a particular venue in a civil action.

3. 15 C. Wright, A. Miller \& E. Cooper, Federal Practice and Procedure $\$ 3801$, at 4 (1976) [hereinafter cited as WRIGHT \& MiLLER].

In state court litigation, an individual state may have an additional interest in protecting its citizens and taxpayers from the undue congestion and expense that may flow from burdening its courts with litigation having no connection with the state. F. JAMES \& G. HAZARD, CIVIL PROCEDURE 659 (2d ed. 1977) [hereinafter cited as JAMES \& HAZARD]. This interest is not present in federal courts, since the cost of maintaining federal courts is borne by all of the nation's taxpayers.

4. Under 28 U.S.C. $§ 1391$ (c) (1976), the federal corporate venue statute, corporate residence can be established by incorporating, obtaining a license to do business, or doing business in the district. Thie "doing business" clause, lowever, does not create interpretation probleins that are within the scope of this Comment, since doing business in one district does not, under the statute, subject the corporation to venue in any other district in the state.

5. The following states lave at least two federal judicial districts: Alabama, Arkansas, California, Florida, Georgia, Illinois, Indiana, Iowa, Kentucky, Louisiana, Michigan, Mississippi, Missouri, New York, North Carolina, Oliio, Oklahona, Pennsylvania, Tennessee, Texas, Virginia, Washington, West Virginia, and Wisconsin. AdMIN. OFFICE OF THE U.S. CoURTS, UNITED STATES COURT DiRectory (1982). Several of these states are important centers of corporate activity. 
poration's "home" district. ${ }^{6}$ The federal courts are split over the issue. Some courts have adopted a "limited venue" position, holding that a corporation can only be sued in a district in which it does business. Other federal courts adhere to a "statewide venue" position, holding that a corporation incorporated or licensed to do business in a state may be sued in any judicial district in that state. In both lines of cases, however, the courts' reasoning is subject to criticism. ${ }^{8}$ This Comment suggests that the consistency of state venue law provides the basis for the resolution of corporate venue issues in the federal courts.

Part I of this Comment discusses the development of the law of venue. Part II analyzes the circumstances surrounding the enactinent of section 1391(c) of the Judicial Code, ${ }^{9}$ the federal corporate venue statute, and suggests that Congress' purpose in enacting the statute cannot be determined with certainty. Part III discusses the federal cases that have interpreted the current venue statute and criticizes the analysis the courts have used to resolve the corporate venue issue. Part IV suggests that the adoption of the limited venue position ${ }^{10}$ would protect the legitimate interests of corporate defendants in obtaining access to convenient forums and at the same time would be consistent with an imphicit national policy in favor of limited venue as expressed through the venue law of the states.

\section{LEGAL BACKGROUND}

Until the enactment in 1948 of section 1391(c) provided special venue rules for corporations, the sanie venue rules were applied to both corporate and individual litigants. Part I of this Comment traces the development of these rules fron their English coinmon law origins to the United States Supreine Court interpretations of the venue statutes in effect when section 1391(c) was passed.

6. Such objections can be expected when litigation in such forums is inconvenient for the corporate defendant. In some cases, however, raising and litigating the issue of improper venue will be more costly than simply acquiescing to the venue selected by the plaintiff.

7. Compare, e.g., Jacobson v. Indianapolis Power \& Light Co., 163 F. Supp. 218 (N.D. Ind. 1958) (advocating limited venue) with Davis v. Hill Eng'g, Inc., 549 F.2d 314 (5th Cir. 1977) (advocating statewide venue). These cases are discussed in Part III of this Comment.

8. Compare Comment, Federal Venue Over Corporations Under Section 1391(c): Plaintiff Corporations, the Judicial District Limitation, and "Doing Business", 12 GA. L. REv. 296, 307-08 (1978) [hereinafter cited as Comment, Federal Venue] (advocating limited venue) with Comment, Federal Practice: Venue in Actions Against Corporations, 19 OKLA. L. REv, 197, 200 (1966) (advocating statewide venue).

9. 28 U.S.C. $\$ 1391$ (c) (1976). For a discussion of other venue problems that have arisen under the federal corporate venue statute, see Cominent, Federal Venue, supra note 8.

10. See supra note 7 and accompanying text. 


\section{A. Development of Venue Doctrine Under English Law}

Early English common law required that jurors evaluate the allegations of parties on the basis of their personal knowledge or investigation. ${ }^{11}$ This rule put narrow geographic limits on venue selection, since only the jurors who lived in the district where the cause of action arose were thought to be able to discharge this responsibility. Thus, all actions had to be tried in the district where the cause of action arose. ${ }^{12}$

The jury's function eventually evolved from investigation to adjudication, and the need for the jury to investigate the facts of each case diminished. This developinent permitted the evolution of a inore liberal concept of venue in certain types of cases. Thus, a distinction developed between local and transitory actions. ${ }^{13}$ An action that could only have arisen in one particular location was deeined to be a local action. ${ }^{14}$ Such an action required the attention of local jurors and could not be litigated in a reinote forum. On the other liand, an action that could have arisen in any location was deemed to be transitory and could be brought wherever the defendant might be found. ${ }^{15}$ Even this more hiberal test, however, required that there be some connection between the forum and either the litigant or the claim. These venue rules formed the basis of the early venue law of the United States.

\section{B. Development of Venue Doctrine Under American Law}

\section{Overview}

The development of federal venue law is best understood in connection with the corresponding development of the geographic scope of federal jurisdiction. ${ }^{16}$ Both venue and jurisdiction rules alternated between traditional common law restrictions and inore liberal rules that permitted a broader geographic scope. ${ }^{17}$ Complicatimg an understanding of federal venue law was the fact that jurisdictional requirements and limitations were incorporated on occasion into the venue statutes. ${ }^{18}$ Thus, early judicial decisions on jurisdictional issues provided some guidance for the development of federal venue law. ${ }^{19}$

\footnotetext{
11. 77 AM. JUR. 2D Venue § 2, at 833 (1975).

12. Id.

13. Id.

14. Such hitigation typically involved real property, which by its nature is immovable. Id. at 834.

15. Id. at $833-34$.

16. Neirbo Co. v. Bethlehem Shipbuilding Corp., 308 U.S. 165, 168-72 (1939); Barrett, Venue and Service of Process in the Federal Courts-Suggestions for Reform, 7 V AND. L. REv. 608, 609-12 (1954).

17. Barrett, supra note 16, at 609-12.

18. Id. at 610 .

19. See Neirbo, 308 U.S. at 169.
} 
Early jurisdictional and venue statutes failed to specify where corporate defendants could be sued, forcing the courts to attempt to resolve the issue. Originally, the courts regarded the corporation as an entity residing "in the place of its creation" which could not "migrate to another sovereignty." 20 This doctrine insulated the corporation from suits in states other than the state of its incorporation, since it had no legal existence in such states. ${ }^{21}$

This limited concept of jurisdiction and venue eventually became outinoded. In the latter part of the 19th century, the corporation became the dominant method of business organization. ${ }^{22}$ During this same period, the developing national economy saw the extension of corporate activities across state lines. Plaintiffs found existing law inadequate to bring such corporations into federal court in the states in which the corporations had done business. The courts recognized that "[t]he fact that corporations did do business outside their originating bounds made intolerable their immunity from suit in the states of their activities."23 The solution to the problein of bringing such corporations into federal court lay in the abandonment of the restrictive interpretation of the jurisdiction and venue statutes.

\section{The Early Statutes}

The Judiciary Act of $1789^{24}$ permitted civil suits in districts where the defendant was an inhabitant or where he could be "found at the time of serving the writ . ..."25 This provision, which caine to be known as the "found" clause, ${ }^{26}$ was qualified by the jurisdictional limitation of diversity suits ${ }^{27}$ to the district where either the plaintiff or the defendant resided. ${ }^{28}$ Courts further limited the choice of venue by requiring that local actions ${ }^{29}$ be brought in the district where the cause of action arose..$^{30}$

The concept of limited venue was eroded by several provisions of

20. Bank of Augusta v. Earle, 38 U.S. (13 Pet.) 519, 588 (1839).

21. 308 U.S. at 169.

22. See Conard, Business Corporations in American Society, in Commentaries on CorpoRATE STRUCTURE AND GovernanCE 41 (D. Schwartz ed. 1979); see generally W. WARNER, THE CORPORATION IN THE EMERGENT AMERICAN SOCIETY (1962).

23. 308 U.S. at 170.

24. Judiciary Act of 1789, ch. 20; $\S 11,1$ Stat. 73,78 (1789). The Act did not dcsignate the appropriate venue for suits against corporations.

25. Id., 1 Stat. at 79.

26. See Neirbo, 308 U.S. at 172.

27. Most federal hitigation at that time was based on diversity jurisdiction. Barrett, supra note 16 , at 609.

28. Judiciary Act of 1789 , ch. $20, \S 11,1$ Stat. at 79 (1789).

29. See supra note 13 and accompanying text; see also 15 WRIGHT \& MILLER, supra note 3, $\S 3822$, at 125 .

30. Blume, Place of Trial of Civil Cases, 48 MiCH. L. Rev. 1, 34 (1949). 
the Judiciary Act of 1875.31 This Act liberalized access to federal courts by eliminating several of the jurisdictional requirements of the 1789 Act. For exainple, the 1875 Act eliminated the rule that, in diversity suits, one or inore of the parties be a citizen of the state where the suit was brought. ${ }^{32}$ At the same time, the Act retained the found clause from the 1789 Act, so that a defendant could be sued in a forum in a state in which either party resided only if the defendant could be found in that state..$^{33}$

\section{Judicial Decisions on Venue over Corporations}

The leading case applying the 1875 Act to a corporate defendant was Ex parte Schollenberger. ${ }^{34}$ In Schollenberger, the Umited States Supreme Court held that a corporation that obtamed a license to do business and designated an agent to receive service of process implicitly waived its right under the 1875 Act to immumity from suit in that state. The Court found the corporation's compliance with state law-which established the corporation's amenability to suit in state court-to be an implied consent ${ }^{35}$ to suit in federal court in that state. ${ }^{36}$ The decision was not based on the fact that the corporation was "found" in tliat district. $^{37}$

The liberalized venue provisions of the 1875 Act proved susceptible to abuse. ${ }^{38}$ In some cases, the formd clause conld be used in combination with the relaxed diversity standards of the Act to bring defendants into court in any foruin in which tley could be served, even if no party was a citizen of the state in which the suit was brouglit. ${ }^{39}$ Congress attempted to rectify the situation by passing the Judiciary Act of 1887.40 This legislation eliminated the found clause, thus preventing defendants from being brought into forums in whicl they had only a transient presence. ${ }^{41}$

The Supreme Court confronted the issue of the effect of the 1887

31. Judiciary Act of 1875 , ch. 137, 18 Stat. 470 (1875).

32. Id.

33. $I d$.

34. 96 U.S. 369 (1878).

35. "Whether . . . surrender of a personal immunity be conceived negatively as a waiver or positivcly as a consent to be sued, is merely an expression of literary preference." Neirbo, 308 U.S. at 168.

36. 96 U.S. at 376 . The issue of whether venue was proper in any district of the state was not present in Schollenberger.

37. Neirbo, 308 U.S. at 173-74.

38. Stonite Prod. Co. v. Melvin Lloyd .Co., 315 U.S. 561,563 (1942).

39. 308 U.S. at 171.

40. Judiciary Act of 1887, ch. 373, 24 Stat. 552 (1887).

41. 308 U.S. at 171. 
Act on corporate defendants in Southern Pacific Co. $v$. Denton.$^{42}$ In Denton, the Court held that the elimination of the found clause precluded the establishment of venue based on the business activity of the corporation in a federal district. ${ }^{43}$ In a previous decision, the Court had lield unconstitutional a state law under which the corporation could have been found to have given an imphed consent to suit in that district. ${ }^{44}$ Thus, the Denton Court found that the only forums in which venue would have been proper were the plaintiff's district of residence or the defendant's district of incorporation.

The Court atteinpted to define the venue implications of the Denton decision in Galveston, Harrisburg \& San Antonio Railway Co. v. Gonzales. ${ }^{45}$ Gonzales held that under Denton, if venue could not be established over a corporation on soine independent grounds, ${ }^{46}$ the corporation could not be subject to suit in any district other than that in which it was incorporated or domiciled ${ }^{47}$ under state law. Gonzales stated that in no previously decided case (including Denton) had there been "any intimation that, where a State is divided into two districts, a corporation shall be treated as an inhabitant of every district of such State, or of every district in which it does business, or, indeed, of any district other than that in which it has its headquarters."48 Several subsequent lower court cases adopted this interpretation of Denton. ${ }^{49}$

The Court repudiated this reading of Denton and its progeny in Neirbo Co. v. Bethlehem Shipbuilding Corp. ${ }^{50}$ In Neirbo, the Court held that the omission of the found clause from the Judiciary Act of $1887^{51}$ did not reflect Congressional intent that corporations be inmune from suit in districts outside their district of incorporation. ${ }^{52}$ Instead, the

42. 146 U.S. 202 (1892):

43. Id. at 207-08.

44. Id. at 207. See supra text accompanying notes 35-36.

45. 151 U.S. 496 (1894).

46. Suit brought in the plaintiffs district of residence is an example of an independent basis for establishing venue.

47. State law required that railroads naintain a public office in the state which was to be regarded as the domicile of the railroad. 151 U.S. at 505.

48. 151 U.S. at 503-04.

49. See, e.g., Platt v. Massachusetts Real-Estate Co., 103 F. 705,705 (C.C. Mass. 1900). These cases are collected in Neirbo Co. v. Bethlehem Shipbuilding Corp., 308 U.S. at 174 n.16.

50. 308 U.S. 165, 174-75 (1939).

51. Act of Mar. 3, 1887, ch. 373, 24 Stat. 552 (repealed 1911).

52. 308 U.S. at 170-71. The Court based this conclusion on the fact that the House version of the Act, im addition to omitting the "found" clause, had contained a provision that eliminated the diversity jurisdiction of the federal courts in actions against corporations. Id. at $172 \mathrm{n} .9$. This provision, however, had been rejected by the Senate. Id. at 172. The Court felt that it would have been "strange indeed" for the House to have restricted corporate venue to a corporation's hoine state by eliminating the "found" clause, and then to have barred foreign corporations froin access to the federal courts altogether through the elimination of diversity jurisdiction in cases involving foreign corporations. Id. 
Neirbo court held that the Schollenberger doctrine of implied consent applied to venue as well as jurisdiction issues. While Neirbo did not explicitly disapprove of the intervening statement in Gonzales - that a corporation was a resident only of the district where it was incorporated-it did reject several lower court decisions that had relied on Gonzales and Denton in holding that venue over corporation was limited to its state of incorporation. ${ }^{53}$ Nevertheless, even tlough $N e$ irbo in effect cast considerable doubt on the continued validity of Gonzales, some courts ${ }^{54}$ continued to regard Gonzales as controlling on the issue of federal corporate venue prior to the Judicial Code Revision. ${ }^{55}$

Thus, under the judicial interpretations of the venue statutes in effect prior to 1948,56 a corporation implicitly consented to be sued in a state by designating an agent to receive service of process or by obtaining a license to do business. Absent such implicit consent, a corporation was a resident-and could be sued-only in the state and district in which it was incorporated. ${ }^{57}$ The Court reaffirmed the validity of this interpretation a few months before Congress adopted the current federal corporate venue statute in the 1948 revision of the United States Judicial Code. 58

II

The Current Corporate Venue Statute

\section{A. Background}

At the time Neirbo was decided, the venue rules developed over the precedimg years had been restated as part of a Judicial "Code." The Code had not, however, achieved the status of positive law. Congress had on several occasions appointed committees to codify the various statutes pertaining to the judiciary, but it had never felt sufficiently satisfied with the final result to replace the Statutes at Large with the codification efforts. Instead, the Code was qualified by a saving clause that rendered it merely prima facie evidence of the law. ${ }^{59}$ The Code could thus be rebutted by proof of the existence of a contradictory "positive" law. 60 Since production of a positive law generally required a time-consuming search through the Statutes at Large, the qualifica-

53. See Platt v. Massachusetts Real-Estate Co., 103 F. at 707; Beech-Nut Packing Co. v. P. Lorillard Co., 287 F. 271, 272 (S.D.N.Y. 1921), cited in Neirbo, 308 U.S. at 174 n.16.

54. See, e.g., Jacobson v. Indianapolis Power \& Light Co., 163 F. Supp. 218, 222 (N.D. Ind. 1958), discussed infra in text accompanying notes 100-124.

55. Id.

56. See infra text accompanying note 62 .

57. Suttle v. Reich Bros. Constr. Co.; 333 U.S. 163, 166-68 (decided Mar. 8, 1948).

58. Id.

59. Preface to The Code of the Laws of the Umited States, 44 Stat. v (1926).

60. Id. 
tion significantly limited the utility of the Code. Thus, in 1948, a new revision of the Judicial Code was enacted in order to establish an organized single source of positive law in this area. ${ }^{61}$

Prior to 1948, federal venue was ostensibly governed by section $51^{62}$ of the pre-revision Judicial Code. That section, however, made no special provision for venue $\mathrm{m}$ actions against corporate defendants. In the 1948 revision of the Code, section 51 was replaced by the more specific provisions of 28 U.S.C. section $1391 .^{63}$ With respect to venue in actions agamst corporate defendants, section 1391(c) provided that "[a] corporation may be sued in any judicial district in which it is incorporated or licensed to do busmess or is doing business, and such judicial district shall be regarded as the residence of the corporation for venue purposes." 64

\section{B. The Revision Process}

Section 1391 (c) might on its face appear to be a significant liberalization of the federal venue requirenents in actions agamst corporations. An analysis of the revision process, however, reveals that this was not necessarily the result Congress intended when it enacted the statute.

61. Senate Comm. on the Judiclary, Revising, Codifying, and Enacting into Law Title 28 of the United States Code, Entitled "Judicial Code and Judiciary," S. Rep. No. 1559, 80th Cong., 2d Sess. 1 (1948) [hereinafter cited as SENATE REPORT], reprinted in LEGISlative History of Title 28, United States Code, "Judiciary and Judicial Procedure," pt. V1, at 1 (R. Mersky \& J. Jacobstein eds. 1971) [hereinafter cited as LEGiSLATIVe HISTORY].

62. Act of Mar. 3, 1911, ch. 231, § 51, 36 Stat. 1087, 1101 (codified as amended at 28 U.S.C. $\S 1391$ (1976)) provided: "[W]here the jurisdiction is founded only on the fact that the action is between citizens of different States, suit shall be brought only in the district of the residence of either the plaintiff or the defendant."

63. 28 U.S.C. \& 1391(a)-(e) (1976) provides as follows:

(a) A civil action wherein jurisdiction is founded only on diversity of citizenship may, except as otherwise provided by law, be brought only in the judicial district where all plaintiffs or all defendants reside, or in which the claim arose.

(b) A civil action wherein jurisdiction is not founded solely on diversity of citizenship inay be brought only in the judicial district where all defendants reside, or in which the claim arose, except as otherwise provided by law.

(c) A corporation may be sued in any judicial district in which it is incorporated or hicensed to do business or is doing business, and such judicial district shall be regarded as the residence of such corporation for venue purposes.

(d) An alien may be sued in any district.

(e) A civil action in which a defendant is an officer or employee of the United States or any agency thereof acting in his official capacity or under color of legal authority, or an agency of the United States, or the Umited States, may, except as otherwise provided by law, be brought in any judicial district in whicli: (1) a defendant in the action resides, or (2) the cause of action arose, or (3) any real property involved in the action is situated, or

(4) the plaintiff resides if no real property is involved in the action. . . .

The summons and complaint in such an action shall be served as provided by the Federal Rules of Civil Procedure except that the delivery of the suminons and complaint to the officer or agency as required by the rules may be inade by certified mail beyond the territorial limits of the district in which the action is brought.

64. 28 U.S.C. $\$ 1391$ (c) (1976). 
Congress recognized the need to revise the Code in the early 1940 's, and delegated ${ }^{65}$ the task of revision to a staff provided by two private law book publishers who had been publishing the "unofficial" Code. The revision staff was responsible to the House Judiciary Subcommittee and worked with the assistance of various consultants and advisory committees. ${ }^{66}$ Congress, however, did not officially begin to consider the work of the revision staff until $1947 .^{67}$

To ensure the enactment of the Code as positive law, unburdened by a saving clause, the revisers told Congress, the judiciary, and the bar that the new Code was basically a restatement of existing law in simplified form. They took pains to point out that substantive changes had been kept to a minimum. ${ }^{68}$ Williain Barron, chief reviser for Title 28 and an employee of one of the pubhishers, testified before the Subcommittee that his staff had "exercised extreme care to avoid any changes of substantive law, concerning which there might be any controversy." ${ }^{169}$ Professor James Moore, a special consultant to the revisers, ${ }^{70}$ testified that "[v]enue provisions have not been altered by the revision."71 Although he immediately qualified this statement by pointing out two "changes of importance" that had been made, ${ }^{72}$ neither of these changes affected section 1391 (c). ${ }^{73}$

After receiving this testimony, the House Judiciary Committee recommended the adoption of the proposed revision. ${ }^{74}$ The Commit-

65. Statutory revision and consolidation is basically a technical process that usually does not result in significant clanges in the law. See United States v. Ryder, 110 U.S. 729, 740 (1884). The personal attention of legislators to the details of such work is generally not required.

66. Revision of Titles 18 and 28 of the United States Code: Hearings on H.R. 2055 Before Subcomm. No. 1 of the House Judiciary Comm, 80th Cong., 1st Sess. 5-8 (1947) [hereinafter cited as Hearings], reprinted in LEGISLATIVE HISTORY, supra note 61, pt. III, at 5-8.

67. Id. at 1.

68. This policy may lave been due to a realization that not all members of Congress would read the proposed revision. Representative Devitt, for example, told the House subcomittee considering the revision, "I know that it is not lumanly possible for the members to read every word or even every section of the bill. . . ." Hearings, supra note 66, at 3 (statement of Hon. Edward Devitt).

69. Id. at 24. Barron referred to the "duty" of the Revision Advisory Committee to inform Congress of any recommended clianges in the law. Barron, The Judicial Code: 1948 Revision, 8 F.R.D. 439, 441 (1948). He also indicated that changes were recommended only where necessary to correct "grave disparities, inconsistencies and ambiguities." Id. (emphasis added).

70. Hearings, supra note 66 , at 25 .

71. Id. at 29. Professor Moore also told the subcommittee that "the revision [as a whole] has made no basic changes." $I d$. at 27.

72. Id. at 29.

73. The changes he pointed out were that (1) improper venue was no longer to be grounds for dismissal (28 U.S.C. § 1406 (1976)), and (2) the courts were given power to transfer a case, for the convenience of parties and witnesses, to another district (28 U.S.C. § 1404 (1976)). Hearings, supra note 66, at 29.

74. House Comm. on the Judiclary, Revision of Title 28, United States Code, H.R. REP. No. 308, 80th Cong., 1st Sess. (1947) [hereinafter cited as HOUSE REPORT], reprinted in LEG- 
tee's report explained how the Revision had been prepared and listed "Examples of Changes in Law."7s With respect to venue, the report stated that "minor changes were inade . . . in order to clarify anbiguities or to reconcile conflicts,"76 and that these changes were "reflected in the reviser's notes." 77 Unfortunately, while the meaning of the reviser's note for section 1391 (c) has never been fully understood, ${ }^{78}$ the note is clearly of no use in determining congressional imtent concerning the geographic scope of corporate residency for venue purposes.

\section{The Aftermath of the Revision}

Following the enactinent of the Code, Barron and Moore were quick to discover new meaning in the revised version of the statute. In the first edition of his treatise on federal practice, Barron stated that "if the state of incorporation has inore than one district, the corporation may be sued in any district thereof, on the theory that it is 'licensed to do business' throughout the whole state."79 Barron recognized that this was a substantial ${ }^{80}$ departure from the previous rule that a corporation would be deeined a resident only of the district where it maintained its principal office and transacted its general corporate business. ${ }^{81}$ Mean-

ISLATIVE HISTORY, supra note 61, pt. IV. The reliance of the House of Representatives on the conclusions of its committees was discussed in WOODROW WILSON, CoNGREssional GovernMENT xvi, 79 (15th ed. 1900), quoted in Ex parte Collett, 337 U.S. 55, 67 n.26 (1949) ("Congressional government is Committee Government. . . . The House sits, not for serious discussion, but to sanction the conclusions of its committees as rapidly as possible.").

75. House REPORT, supra note 74 , at 5-7.

76. Id. at 6.

77. Id. The Reviser's Note for $\$ 1391$ (c) stated:

In subsection (c), references to defendants "found" within a district or voluntarily appearing were omitted. The use of the word "found" made section 111 of Title 28, U.S.C. 1940 ed., ambiguous. The argument that an action could be brought in the district where one defendant resided and a nonresident defendant was "found," was rejected in Camp v. Gress, 1919, 39 S.Ct. 478, 250 U.S. 308, 63 L.Ed. 997. However, this ambiguity will be obviated in the future by the omission of such reference.

Appendix to House REPORT, supra note 74, at A127. SENATE REPORT, supra note 61, at 2, indicating the reliance placed on the Reviser's Notes, states that the Notes "explain in great detail the source of the law." However, subsequent evaluations of the note for $\$ 1391$ (c) indicate some dissatisfaction with its content. See, e.g., 1 J. MOORE, J. LuCAS, H. FINK, D. WECKsteIN \& J. WiCKer, MOORE's Federal Practice \] 0.142 [5.-1-3], at 1398 n.l (2d ed. 1982) [hereinafter cited as MOORE's Federal Practice]; Davis v. Hill Eng'g, Inc., 549 F.2d 314, 322 n.11 (5th Cir. 1977) (commenting on inadequacy of note). See also Wright, Forword (sic) to Legislative HistoRY, supra note 61, at iii ("The Reviser's Notes suggest that often the Reviser was wholly unaware of the significance of what he was doing.").

78. See supra note 77.

79. W. Barron \& A. holtzoff, Federal Practice \& Procedure With Forms \$ 80, at 154 (1950). Technically, this statement is inaccurate, since a license to do business is usually obtained by a company not wishing to imcorporate in a state.

80. Barron stated that Congress took a "long step" beyond Neirbo in enacting $\$ 1391$ (c). Id.

81. Id. (citing 35 C.J.S. Federal Courts $\$ 21$, at 822, 823 (1943)). Standard Stoker Co. v. Lower, 46 F.2d 678 (D. Md. 1931), was cited by the authors of C.J.S. in support of the proposition that where residence is the determining factor, a corporation could be sued only in the district in 
while, Professor Moore's Judicial Code Commentary, ${ }^{82}$ published shortly after the revision was enacted, stated that "[f]or venue purposes [the Code] has . . . radically altered the rule relative to a corporate defendant," ${ }^{83}$ which under section 1391(c) could "be a resident of many districts for purposes of applying the above $\left[{ }^{84}\right]$ venue rules, whereas formerly a corporation was a resident of only one district." 85

The contradiction between the pre- and post-Revision statements of Barron and Moore makes it difficult to ascertain the Congressional intent im enacting section 1391(c). Unfortunately, most courts have not acknowledged the existence of this contradiction. Courts that have cited the pre-enactment comments of Barron and Moore fail to cite their post-enactment work, ${ }^{86}$ while courts citing the post-enactment work often do not cite the pre-enactment comments. ${ }^{87}$ For example, in

which it kept its principal office, and thus could not be sued in another district in the state. 35 C.J.S. Federal Courts $\$ 21$, at 823 n.31 (1943). Standard Stoker, however, was among the cases repudiated by the Supreme Court in Neirbo. See 308 U.S. at 174 n.16.

Professor Wright also felt that $\$ 1391$ (c) went "far beyond" Neirbo. C. Wrighr, HaNDBooK of the LAW OF Federal Courts $153-55$ \& n.35 (2d. ed. 1970), 174 \& n.39 (3d ed. 1976).

82. J. Moore, Moore's Judicial Code Commentary (1949) [hereinafter cited as MOORE's Judicial Code CommentaRy].

83. Id. \0.03(28), at 194 (emphasis in original). The emphasis in the treatise was provided to indicate that the enactment of $\& 1391$ (c) did not alter venue law for corporate plaintiffs. See also $i d$. at 174 ("the Code has greatly qualified the doctrine [that a corporation is a resident of the state in which it is incorporated]").

Professor Moore cited Galveston, H. \& S.A. Ry. v. Gonzales, 151 U.S. 496 (1894), for the proposition that prior to the adoption of the revision, a corporation was a resident of the state in which it was imcorporated. Id. at 174 . He also stated that while Neirbo had not altered the Gonzales rule, id. at 174, $194 \mathrm{n} .124, \S 1391$ (c) did change the Gonzales rule. Id. at 174, 178, 194. But see supra text accompanying note 49 (suggesting that Neirbo unay have implicitly overruled Gonzales).

84. The provisions referred to were 28 U.S.C. $\S \S 1391$ (a) and (b) (1976).

85. MOORE's Judicial CODE COMMentary, supra note $82, \llbracket 0.03(28)$, at 178 (footnotes omitted).

In Comment, Federal Venue, supra note 8, at 306, the author suggests that Professor Moore's statement regarding a "radical alteration" of prior law by the Judicial Code revision referred to the possibility of using $\S 1391$ (c) to define residence for the purposes of $\S \S 1392$ and 1393, and not to the possibility that $\$ 1391$ (c) established corporate residence in inore than one district for purposes of venue. This position is not tenable in light of the repeated references that Professor Moore made to the alteration of the Gonzales rule by $\$ 1391$ (c). The Comment also claims that in the 1977 edition of his treatise, Professor Moore "cited, with apparent approval, [a] restrictive view of venue under section 1391(c)." Comment, Federal Venue, supra note 8, at 307. The treatise, however, actually cites both lines of cases without taking a position as to the validity of either. Moore's Federal Practice, supra note 77, 10.142 [5.-1-3], at 1407 n.31.

86. See, eg., Fourco Glass Co. v. Transmirra Prod. Corp., 353 U.S. 222, 227 n.8 (1957).

87. See, e.g., Garbe v. Humiston-Keeling \& Co., 143 F. Supp 776, 778 (E.D. Ill. 1956), rev'd on other grounds, 242 F.2d 923 (7th Cir.), cert. denied, 355 U.S. 846 (1957); $c f$. Gulf Research \& Dev. Co. v. Schlumberger Well Survey Corp., 98 F. Supp. 198, 200 n.8 (D. Del.), writ of mandamus denied sub nom. Gulf Research \& Dev. Co. v. Leahy, 193 F.2d 302 (3d Cir. 1951), affd, 344 U.S. 861 (1952) (per curiam), which cites Professor Moore's pre-enactunent statement to the House Judiciary Subcommittee, supra note 71, and his post-enactment opinion on the effect of § I391(c), 
Fourco Glass Co. v. Transmirra Products Corp. ${ }^{88}$ the Supreme Court observed that "[s]tatements made by several of the persons having importantly to do with the 1948 revision are uniformly clear that no changes of law or pohicy are to be presumed from changes of language in the revision unless an intent to make such changes is clearly expressed." 89 In support of this observation, the Court cited the pre-enactment statements of Barron and Moore ${ }^{90}$ but did not cite their postenactment statements. Although Fourco did not imterpret section 1391(c), ${ }^{91}$ its reasoning has been used by some lower courts to interpret that statute. ${ }^{92}$ The failure to recognize the ambiguity created by these conflicting statements tends to reduce the persuasive force of these opinions.

III

Judicial INTERPRETATIONS OF THE CURRENT FEDERAL Venue STATUTE

The Supreme Court has never provided a definitive interpretation of section 1391(c) as it apphies to federal venue agamst corporations in multidistrict states. In view of the confused legislative history of the Judicial Code revision, ${ }^{93}$ it is not surprising that the lower federal courts have produced contradictory interpretations of the federal corporate venue statute. ${ }^{94}$ Without clear language on the face of the statute and clear evidence of congressional intent, courts lack objective standards for decision of this issue. As a result, several decisions have been based on subjective - and thus unpredictable - evaluations of the hardships imposed by statewide venue. ${ }^{95}$ Soine courts ${ }^{96}$ have adopted a "statewide venue" interpretation, holding that a corporation's residency extends to every federal district of every state in which it has either filed articles of mcorporation or obtained a license to do busi-

supra note 85 , but does not comment on the inconsistency between the two statements. The postenactment statements cannot, of course, be considered reliable indicators of Congressional intent.

88. 353 U.S. 222 (1957).

89. Id. at 227.

90. Id. at 226 n.7.

91. Fourco involved 28 U.S.C. $\$ 1400$ (b) (1948), whicl governs venue in patent infringement cases. 353 U.S. at 222.

92. See, e.g., Jacobson v. Indianapolis Power \& Light Co., 163 F. Supp. at 223, discussed infra in text accompanying notes 102-24.

93. See supra text accompanying notes 68-85.

94. See WRIGHT \& MLLER, supra note 3, § 3811 at 62-63; MOORE's FEDERAL PRACTICE, supra note 77, I 0.142 [5.-1-3], at 1407 n.31.

95. Compare, e.g., Davis, 549 F.2d at 314 (discounting hardships of statewide venue) with Fuller \& Dees Mktg. Group v. Outstanding Am. High School Students, 335 F. Supp. 913, 915 (M.D. Ala. 1972) (noting hardships of statewide venue as a justification for limited venue).

96. See, e.g., Davis v. Hill Eng'g, Inc., 549 F.2d 314 (5th Cir. 1977) 
ness. Other courts ${ }^{97}$ have adopted a "limited venue" position, under which a corporation is a resident only of the federal district in which it is incorporated or hicensed under state law. ${ }^{98}$ At present, the cases reveal no clear trend. ${ }^{99}$

\section{A. The "Limited Venue" Position}

The leading ${ }^{100}$ argument for the view that a corporation can be sued only in the district of incorporation ${ }^{101}$ is found in Jacobson $v$. Indianapolis Power \& Light Co. ${ }^{102}$ In Jacobson, an Illinois resident sued two Indiana corporations in the federal district court for the Northern District of Indiana. ${ }^{103}$ The defendants contended that venue in the Northern District was improper, ${ }^{104}$ since neither corporation was doing business in that district, ${ }^{105}$ and each maintained its principal place of business in the Southern District of Indiana. ${ }^{106}$

In deciding whether, under section $1391(\mathrm{c})$, the defendant corporations were incorporated in all of the federal judicial districts in Indiana, the Jacobson court first noted that prior to the 1948 revision of the Judicial Code, the Gonzales rule was "unquestionably controlling" on the issue of proper corporate venue. ${ }^{107}$ The Gonzales rule provided that, for federal venue purposes, a corporation is an inhabitant and resident

97. See, e.g., Jacobson v. Indianapolis Power \& Light Co., 163 F. Supp. 218 (N.D. Ind. 1958).

98. For convenience, such a district will hereinafter be referred to as the "district of incorporatiou."

99. Compare C. WRIGHr, supra note $81, \S 42$, at $174-75$ (3d ed. 1976)("trend seeuns to be that if a corporation is doing business in only one district of a state, it inust be sued in that district even though it is incorporated in the state or licensed to do business throughout the state") with MOORE's Federal PRACTICE, supra note 77, 70.142 [5.-1-3] n.31 (1981-82 Supp.) (cases cited take position that a license to do business throughout the state inakes venue proper in all districts of the state), C. WRight, HANDBOOK OF THE LAW OF FEDERAL CoURTs, $\$ 42$, at 154 (2d ed., 1970) (prerevision rule that corporation incorporated within a state could be sued only in the district where it kept its principal office and transacted its general corporate business "is probably no longer the law" under § 1391(c)) and JAMES \& HAZARD, supra note 3, at 617-18 (under \& 1391(c), corporate defendant is deented to be a resident of all districts in the state of its incorporation, and probably of all districts in other states in whicl it is licensed to do business).

100. See also, eg., Educatioual Dev. Corp. v. Economy Co., 376 F. Supp. 287 (N.D. Okla. 1973); Westcrinan v. Grow, 198 F. Supp. 307 (S.D.N.Y. 1961); Sawyer v. Soaring Soc'y of Ant., Inc., 180 F. Supp. 209 (S.D.N.Y. 1960). No federal appellate court lras adopted a limited venue position.

101. For the purposes of this Comment, no distinction will be drawn between incorporation and hicensure. A corporation that is incorporated in State $A$ may obtain a license to do business in State $B$ if it does not wish to incorporate in that state. See Jacobson v. Indianapolis Power \& Light Co., 163 F. Supp. at 220.

102. Id. at 218.

103. Id. at 219-20. Jurisdiction was based on diversity of citizenship. Id.

104. Id.

105. Id. at 224.

106. Id. at 220. The aceident also oceurred in the Southern District of Indiana. Id.

107. See supra text accoinpanying note 6 . 
only of its home $e^{108}$ district. ${ }^{109}$

The court then considered whether section 1391(c) was intended to broaden venue with respect to corporate defendants. It conceded that a hteral reading of the language in section 1391(c) made "plausible"110 the statewide venue position urged by the plamtiff. ${ }^{111}$ The court found it equally plausible, however, that Congress imtended the phrase "in which it is incorporated" to refer only to a single district within the state of incorporation. ${ }^{112}$ Consequently, it attempted to discover Congress' intent in enactimg the law. Adopting the Supreme Court's holdmg in Fourco Glass Co. v. Transmirra Products Corp. ${ }^{113}$ that the 1948 revision was not to be presumed to change the law unless such changes were clearly expressed, ${ }^{114}$ the Jacobson court concluded that Congress had not intended to change the existing law of corporate venue. ${ }^{1 \text { is }}$

In reaching this conclusion, the Jacobson court erroneously relied on Fourco as the sole basis for its interpretation of Congress' intent in enacting section 1391(c). The statutory provision interpreted by the Supreme Court in Fourco had not been substantively altered by the 1948 revision. ${ }^{116}$ Section 1391(c), by contrast, was not only a completely new addition to the existimg body of statutory law, ${ }^{117}$ but on its face appeared to go beyond the Supreme Court's decisions on corporate venue. ${ }^{118}$

The Jacobson court also incorrectly presumed that Congress regarded Gonzales ${ }^{119}$ as the controlling Supreme Court interpretation of the pre-revision federal venue statute as applied to corporations. ${ }^{120}$ As discussed earlier, ${ }^{121}$ the precedential strength of Gonzales was at

108. See supra text accompanying note 48 .

109. 163 F. Supp. at 222. The Jacobson court apparently felt that Neirbo had not altered the Gonzales rule, since Neirbo was not cited in the court's discussion of prior venue law. $I d$. at 22122. $C$. supra text accompanying note 53 (suggesting that $N e$ irbo at least implicitly overruled Gonzales).

110. Id.

111. According to the Jacobson court, the plaintiff contended that $\$ 1391$ (c) should be read: "A corporation may be sued in any judicial district [in the statel in which it is incorporated . . .." Id.

112. Id.

113. 353 U.S. 222 (1957), discussed supra in text accompanying notes 88-89.

114. Id. at 227 .

115. 163 F. Supp. at 223.

116. 353 U.S. at 226. Cf. Pure Oil Co. v. Suarez, 384 U.S. 202, 204 (1966) (purpose and effect of $\$ 1391(c)$ was to broaden general venue requirements in actions against corporations by providing a forum in any judicial district in which corporate defendant "is doimg business").

117. See supra text accompanying notes 63-64.

118. See supra text accompanying notes 63-64.

119. Galveston, H. \& S.A. Ry. v. Gonzales, 151 U.S. 496 (1894), discussed supra in text accompanying notes $45-48$.

120. 163 F. Supp. at 223.

121. See supra text accompanying notes 53. 
least indirectly called into question by Neirbo. Furthermore, whether Congress was aware of Gonzales or not, ${ }^{122}$ it should not have been required to repudiate that case explicitly if the words of the statute indicated a clear congressional intent to expand the availability of venue in actions against corporations. ${ }^{123}$

Thus, while the Jacobson court's conclusion is consistent with the limited venue theory advocated in this Comment, its analysis is not persuasive. Although several federal district courts have followed Jacobson, ${ }^{124}$ numerous other federal courts have rejected its reasoning, and have instead adopted the arguinents for statewide venue discussed in the next section.

\section{B. The "Statewide Venue" Position}

\section{Adoption of the Statewide Venue Position in Davis}

Davis v. Hill Engineering, Inc. ${ }^{125}$ is the leading case advocating the statewide venue position. ${ }^{126}$ In Davis, the plaintiff sued a Texas corporation under the Jones Act. ${ }^{127}$ Although the corporation's principal place of business was in the Southern District of Texas, ${ }^{128}$ the suit was filed in the federal district court for the Eastern District of Texas. The defendant corporation contended that venue was improper because it was not doing business in the Eastern District. ${ }^{129}$ This contention was rejected by the district court, and was raised again on appeal. ${ }^{130}$ The Fifth Circuit Court of Appeals, stating that it did not agree with the

122. Where it cannot be shown that Congress was aware of a Supreme Court decision interpreting a statute, awareness cannot be presumed. Zuber v. Allen, 396 U.S. 168, 185-86 n.21 (1969). But see Lorillard v. Pons, 434 U.S. 575, 580 (1978) (dictum) (Congress is presumed to be aware of a judicial interpretation of a statute and to adopt that imterpretation when it reenacts a statute without a change.).

123. See Ex parte Collett, 337 U.S. 55, 61 (1949); Gemsco, Inc., v. Walling, 324 U.S. 244, 260 (1945). The courts are split on the issue of whether or not the language of $\S 1391(\mathrm{c})$ is ambiguous. Compare Richards v. Upjohn Co., 406 F. Supp. 405, 406 (E.D. Mich. 1976) (language of $\$ 1391$ (c) unambiguously authorizes statewide venue) with Educational Dev. Corp. v. Economy Co., 376 F. Supp. at 289 (since language of $\S 1391$ (c) is ambiguous, limited venue is appropriate on policy grounds).

124. See, e.g., Educational Dev. Corp. v. Economy Co., 376 F. Supp. at 288-89; Westerman v. Grow, 198 F. Supp. at 308.

125. 549 F.2d 314 (5th Cir. 1977).

126. The "statewide venue" opinions prior to Davis were issued by district courts. See, e.g., Richards v. Upjohn Co., 406 F. Supp. 405 (E.D. Mich. 1976). First Sec. Bank of Utah v. Aetna Casualty \& Sur. Co., 541 F.2d 869 (10th Cir. 1976), considered the related issue of federal claim venue against a corporate defendant in Utah-a single district, multidivision state.

127. 46 U.S.C. $§ 688$ (1977). Venue under the Jones Act is controlled by 28 U.S.C. $\S 1391$ (c). 549 F.2d at 320 .

128. 549 F.2d at 319 .

129. Id. at 320.

130. Id. at 319. 
Jacobson court's analysis, affirmed the district court on this issue..$^{131}$

The Davis court made three arguments in support of its holding that a corporation doing busimess in a state can be sued in any federal district in that state. First, the court argued that in adopting the Revision Committee's proposed language for section 1391(c), Congress must have been aware that a state certificate of imcorporation gives a busmess the right to operate throughout the state, not just in one district. ${ }^{132}$ Therefore, Congress probably intended statewide venue to apply in the federal courts as well. Second, im enactimg section 1391(c), Congress did not intend that corporations receive disparate venue treatment depending on whether they were licensed to do business, doing busimess, or imcorporated in a particular district. ${ }^{133}$ The court pointed out that "the language of the statute makes no distinction among the three types of corporate activities." 134 Third, the forum's distance from the corporation's activities is not a relevant basis for determining proper venue under section 1391(c), simce a busmess may be imcorporated in a state having no connection to its activities ${ }^{135}$ and still be subject to venue in that state. Davis therefore rejected policy arguments that a corporate defendant should not have to respond to suits far from the center of its corporate activity, ${ }^{136}$ statimg that if the corporation found the forum truly inconvenient, it could apply for a change of venue under 28 U.S.C. section 1404(a).

\section{A Critique of Davis}

The Davis court's reasoning is objectionable on several grounds. First, it is doubtful that Congress paid any specific attention to section 1391(c) when it adopted the work of the revision staff. As has been shown, section 1391 (c) was only one part of a comprehensive revision of the Judicial Code. The revision was written not by Congress itself, but by a staff of revisers working under a contract with the House Judiciary Subcommittee. The subcommittee in turn adopted the revisers' recommendations without significant change. Committee reports on the revision ${ }^{137}$ imdicated to all members of Congress that venue law would not be significantly changed. In view of the uncontroversial nature of the revision, there is ample reason to believe that Congress relied, as it traditionally does, ${ }^{138}$ on the work of its committees, and was

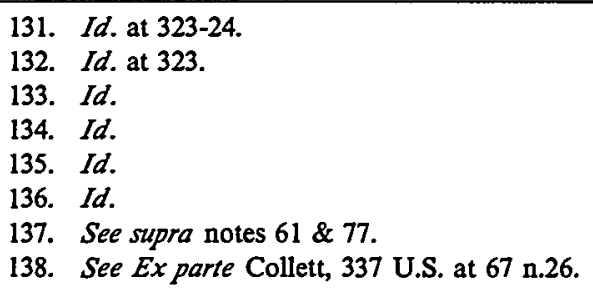


not aware of any expansive implications of section 1391(c). Therefore, there is scant support for the position that Congress specifically intended to change this aspect of venue law.

Second, even if Congress were aware of the statewide effect of a certificate of incorporation or a license to do business issued pursuant to state law, ${ }^{139}$ the legislative history of the Judicial Code Revision does not indicate that Congress relied on this factor to create statewide venue in federal district courts. In fact, the Davis court's analysis on this point ignores an additional crucial fact: at the time of the revision, only one state ${ }^{140}$ had chosen to subject corporations chartered under its laws to the risk of having to defend lawsuits in counties having no connection with either one of the parties or with the litigation itself. ${ }^{141}$

As for the Davis court's argument that Congress in enacting section 1391(c) made no distinction between the activities of incorporation, obtaining a license to do business, and doing business, this Comment suggests that a distinction between the first two activities and

139. Although Congress may create corporations which serve as instrumentalities of the federal government, venue in an action agamst such a corporation would, absent a Congressional provision to the contrary, be governed by 28 U.S.C. $\S$ 1391(e). See supra note 63.

140. Until recently, DEL. CoNST. art. I, $\$ 9$, required that actions shall be tried in the county where commenced, unless the defendant could show that it could not receive an impartial trial in that county. In 1977, however, the Delaware Constitution was amended to eliminate this restriction on change of venue. 61 Del. Laws 116 (1977). Furthermore, DEL. CODE. ANN. tit. 10, $\$ 5102$ (1974) provides that a plaintiff shall not be awarded costs if the defendant resides in a county other than that in which the action is brought. The constitutionality of this statute was upheld in Wood v. Short, 13 Del. 112, 12 A. 247 (Ct. Err. \& App. 1888).

141. Forty-seven of the forty-eight states provided for limited venue. See Ala. Code tit. 7 , $\S 60$ (1940); ARIz. CODE ANN. \& 21-101 (1939); ARK. Stat. AnN. § 27-605 (1947); Cal. Const. art. 12, \& 16 (1879); Colo. STat. ANN. ch. 41, § 18 (1935); ConN. Gen. STAT. $\$ 7747$ (1949); Fla. STAT. § 46.04 (1941); GA. CODE ANN. \& 3-206 (1933); IDAHo CODE ANN. § 5-404 (1932); [IIl.] Civ. Prac. Act $\$ 8(1)$, Ill. Rev. Stat. ch. 110, § 8(1) (Cahill 1933); Ind. STAT. ANN. \$\$ 2-703, 2-706 (Burns 1933); Iowa Code §616.14 (1946); KAN. GEN. STAT. § 60-504 (1935); KY. CIv. CODE OF Practice \$ 72 (Carroll 1932); LA. Gen. Stat. ANN. \$ 1249 (1939); ME. ReV. STAT ch. 99, § 13 (1944); MD. Code ANN. art. 23, \$§ 103, 118 (1924); MASS. Rev. Laws ch. 223, \& 8 (1932); Mich. Stat. ANN. § 27A.I625 (1936); MINN. STAT. \$ 9214 (1927); MISS. Code § 1433 (1942); Mo. REv. Stat. § 874 (1939); Mont. Rev. Code § 93-2904; (1947); Neb. Rev. STAT. § 25-405 (1943); Nev. CoMp. Laws $\$ 8571$ (1929); N.H. Rev. Laws ch. 384:1 (1942); N.J. REv. STAT. tit. 2, § 27-19 (1937); N.M. STAT. ANN. § 19-501 (194I); N.Y. Civ. PRAC. ACT ANN. § 182 (Gilbert-Bliss 1920); N.C. CODE § 466 (1935); N.D. Rev. CODE § 28-04-04 (1943); OHIo CODE ANN. § 11272 (Throckmortou 1940); OKIA. Stat. tit. 12, § 134 (1941); OR. CoMP. Laws ANn. \& 1-403 (1940); PA. STAT. tit. 12, §§ 1309, 1310 (Purdon 1936); R.I. GEN. LAWs ch. 511, § 3 (1938); S.C. CoDE $\S 422$ (1942); S.D. CODE § 33.0304 (1939); TENN. CODE $\$ 8643$ (1932); TEX. Civ. STAT. art. 1995(2I, 23) (Vernon 1936); UTAH Code ANN. \& 104-4-7 (1943); VT. Stat. Rev. § 1604 (1947); VA. COdE ANN. $\$ 6049$ (1936); Wash. Rev. Stat. ANN. \$ 205-I (Remington 1932); W. VA. Code ANN. \$§ 4937, 5517, 5538 (1943); WIS. STAT. § 261.01(6) (1943); Wyo. CoMP. STAT. § 3-805 (1945). Alaska and Hawaii had not been admitted to statehood at the time the judicial code revision was adopted.

Not all of the states specifically provided for venue in actions against corporate defendants. In such situations, however, a corporation is considered a resident of the county or district where its principal office or place of business is located. 18 C.J.S. Corporations $\$ \& 8(b), 176(b)$ (1939). 
the third is apparent on the face of the statute. Both incorporation and hicensure require that a corporation accept the obligations of the laws of the incorporating state. The corporation is also entitled, however, to enjoy the benefits of that state's law. Thus, state law may require the designation of an agent to receive service of process, ${ }^{142}$ but at the same time contain venue provisions that protect tlie corporation from liaving to defend lawsuits in all counties in the state. ${ }^{143}$

On the other hand, a corporation "domg business" without the benefit of either incorporation or licensure in effect acts in defiance of state law. Many states recognize this distimction by providimg that foreign corporations, not autliorized to do busmess in the state through imcorporation or licensure, may be sued in any county or district in the state. ${ }^{144}$ Moreover, of the three types of corporate activity that establisl1 venue under section 1391(c), "doimg business" is the only activity whicl by itself can subject a corporation to hability. ${ }^{145}$ Since such liability is most likely to arise in the geographic areas where business activity occurs, corporations can be expected to anticipate litigation in those areas and thus to take appropriate precautionary measures. Subjectimg the corporation to venue in a district where the corporation is doing business is therefore not unduly burdensome.

If the Davis court had recognized the distinction between doing busmess and incorporation or licensure, it would probably have recognized the inconsistency of its statewide venue position. As a result of this inconsistency, an "unauthorized"146 corporation may enjoy the privilege of limited federal venue under the "domg business" clause. A corporation which complies witl state law, however, will have to assume the risk, under the incorporation or licensure clauses of section 1391(c), of defending in any federal district in the state, regardless of the existence or extent of its business activity in that district.

The Davis court's argument that the forum's distance from the place of corporate activity is not a relevant basis for determining venue $^{147}$ is also defective. It is true that, in many cases, a business inay choose to incorporate in a state far froin the site of its corporate activity. It knows, however, that under state law it will only be subject to

142. See, e.g., ILl. ANN. Stat. ch. 32, § I57.11 (Smith-Hurd 1954).

143. See infra note 154.

144. See, e.g., Civil Practice Act $\S 5$, Ill. AnN. STat. ch. 110, § 5 (Smith-Hurd Supp. 198283); IoWA CODE ANN. $\$ 496$ A.11 (West 1962); MiNN. Stat. ANN. $§ 542.09$ (West Supp. 1982).

145. Incorporation and hicensure are essentially neutral activities that can only result in liability if the corporation causes harm to another party by subsequently "doing business," under the license or certificate of incorporation. For example, a corporation might inisrepresent the extent of its capitalization and thereby frauduleutly obtain a loan, but the resulting harm would be caused by doing business (obtaining the loan) rather than the act of incorporation itself.

146. See supra text preceding note 144.

147. 549 F.2d at 323. 
venue in the county of its registered address. Furthermore, it can anticipate to some degree the type and quantity of litigation it will face in that state. ${ }^{148}$ A decision to incorporate in such a state is presumably undertaken with either full advance knowledge or, at least, an opportunity to investigate the risk of having to litigate in the remote location. If a corporation chooses to incorporate in a remote state, it can, to a certain extent, ${ }^{149}$ limit the risk of litigating in inconvenient foruns by choosing the location of its registered address, or geographically limiting its business activity. Thus, it can calculate the cost of litigation in that state and can be presumed to have assunned the risk of incurring the expenses involved in sucli litigation. It is a different matter to require, as the Davis court did, that a business which incorporates in such a state should expect to be subject to venue in any district in that state, since predicting the costs of litigation in such a situation is nuch enore difficult.

The Davis court's suggestion that a severely inconvenienced corporate defendant move for a section 1404(a) transfer would not have been necessary if the court had dealt nuore directly with the proper interpretation of section $1391(\mathrm{c})$. It is unfair to force a corporation to litigate the section 1404(a) issue to get the result that would have been reached under a limited venue rule. Furthermore, the forum non conveniens rule embodied in section 1404(a) explicitly involves an exercise of discretion by a district court judge. ${ }^{150}$ Since federal judges have exhibited varying degrees of reluctance to disturb the plaintiff's choice of forum, ${ }^{151}$ the "remedy" proposed by the Davis court would saddle corporate defendants with the unwarranted burden of proving inconvenience and, if they did not prevail, would expose them to an undue risk of hitigation in an inconvenient forum.

Finally, the Davis court failed to recognize that the language of section 1391(c) could be construed either in support of or against state-

148. Assuming that the corporation does no business in the reinote state, most of the litigation im the state of incorporation will involve problems with the corporation's organizational structure. Litigation brought by persons harmed by the corporation's products or injured by the conduct of its employees be brought where the plaintiff resides, or where the corporation does business.

149. In many cases, an independent basis for establishing venue-such as the plaintiff's residence-will not be within a corporation's direct control. However, by selecting its place of business within a given state, the corporation can eliminate some uncertainty, because it can reasonably predict that most of the people with whom it does business will live in the saine general geographic area.

150. JAMES \& HAZARD, supra note $3, \S 12.29$, at 658.

151. Compare Kawecki Berylco Indus., Inc. v. Fansteel, Inc., 512 F. Supp 984, 986 (E.D. Pa. 1981) (plaintiffs forum choice will necessarily weigh against any proposed transfer), affd mem ., 676 F.2d 686 (1982) with Vassallo v. Niedermeyer, 495 F. Supp. 757, 759 (S.D.N.Y. 1980) (while plaintiff's choice of forum is a factor to be considered on a inotion for change of venue, it is not entitled to "near-decisive" weight). 
wide venue. ${ }^{152}$ In liglit of this ambiguity and the uncertam legislative history of the statute, the Davis court sliould have more fully considered relevant policy factors before deciding that statewide venue was appropriate. Part IV of this Comment offers sucl1 an analysis.

\section{IV}

\section{A Proposed Federal Venue Standard}

This Comment proposes that federal courts considering the issue of the geographic scope of venue in actions against corporate defendants under section 1391 (c) should adopt a limited venue position. ${ }^{153}$ Section A of this Part argues that limited venue would be consistent with an implicit national policy, as expressed through the consistency of the venue laws of the states, in favor of limited venue. It also suggests that limited venue would lead to an efficient and consistent resolution of venue issues. Section $B$ considers a possible objection that the proposal represents a threat to the rule that state law should not determime the outcome of federal procedural issues.

\section{A. Justification for Adoption of the Proposed Standard}

The basis of the proposal advocated by this Comment is the uniformity of state corporate venue law. Both currently ${ }^{154}$ and the time of

152. See supra note 123 .

153. See supra text accompanying note 97.

154. Ala. Code \& 6-3-7 (1975); Alaska Stat. \$ 22.10.030 (1980); ARIz. Rev. Stat. AnN. $\S 12-401$ (1982); Ark. Stat. AnN. § 27-605 (1979); Cal. Civ. Proc. Code § 395.5 (West 1973); Colo. R. Civ. P. 98; Conn. Gen. STAT. ANN. \$ 51-345(3) (West Supp. 1982); Del. Code ANN. tit. $10, \S 5102$ (1974) (provides only for forfeiture of plamtiff's costs if action brought in any county other than county of defendant's residence; see supra note 140); FLA. STAT. ANN. $\$ 47.051$ (West Supp. 1982); GA. Code ANN. § 14-2-63 (1981); Hawall Rev. STAT. § 603-36 (1976); IdAHo CodE $\S 5-404$ (1979); [Ill.] Code Civ. Proc. $\$ \S 2-101,-102$, Ill. ANN. STAT. ch. 110, \& 2-101, -102 (Smith-Hurd Supp. 1982); IND. R. TRIal P. 75 (1981); IOWA CodE ANN. \& 496A.11 (West 1962); Kan. Civ. Proc. Code Ann. \$ 60-604 (1976); Ky. Rev. Stat. ANN. § 452.450 (Baldwin 1981); La. Code Crv. Proc. AnN. art. 42 (West Supp. 1982); ME. Rev. Stat. AnN. tit. 4, § 155 (1979); MD. Cts. \& Jud. Proc. Code AnN. \& 6-201 (1980); Mass. Gen. Laws ANn. ch. 223, \& 8 (West 1958); Mich. Comp. Laws. ANN. $\$ 600.1621$ (West 1981); MinN. STat. ANN. $\$ 542.09$ (West Supp. 1982); Miss. Code AnN. \&11-11-3 (1972); Mo. ANN. STat. § 508.040 (Vernon 1952); Mont. Code ANN. \& 25-2-108 (1981); NEb. Rev. Stat. § 25-405 (1979); NEv. REv. STAT. \$ 13.040 (1979); N.H. Rev. Stat. ANN. § 507:9 (1968); N.J. Civ. PRAC. R. 4:3-2; N.M. STAT. ANn. § 38-3-1 (Supp. 1979); N.Y. Clv. PRAC. LAW $\$ 503$ (McKinney 1976); N.C. GEN. STAT. \$§ 1-79, 1-80 (Supp. 1981); N.D. Cent. Code § 28-04-04 (1974); Ohio R. Civ. P. 3(B); OkLA. STat. ANn. tit. 12, \&§ 134, 137 (West Supp. 1981); OR. Rev. Stat. $\$ 14.080$ (1981); PA. Stat. ANN. tit. 12, \& 2179 (Purdon 1975); R.I. GEN. Laws \& 9-4-4 (Supp. 1981); S.C. CodE ANN. \& 15-7-30 (Law. Co-op. 1977); S.D. CoMP. Laws ANN. \$15-5-6 (Supp. 1981); TenN. Code ANN. \$\$ 20-4-104,106 (1980); TeX. Civ. Code ANN. § 1995(23) (Vernon 1964); UTah Code ANN. § 78-13-7 (1977); VT. STAT. ANN. tit. 12, $\$ \S 402,405$ (1973 \& Supp. 1981); VA. CODE $\$ \$ 8.01-257,-260$ to -262 (1977 \& Supp. 1982); WASH. Rev. Code ANN. $\$ 4.12 .025$ (Supp. 1982); W. VA. Code $\S 56-1-1$ (1966); WIS. STAT. ANN. $\S 801.50$ (West 1977); WYO. STAT. \& 1-5-105 (1977). 
the revision of the Judicial Code, ${ }^{155}$ state venue law has adopted the limited venue position and rejected the statewide position. The uniform result reached under the venue laws of the states, considered as a whole, ${ }^{156}$ is an objective factor which should be given significant weight by courts deciding the geographic scope of federal venue under section 1391 (c). ${ }^{157}$

Use of the homogenous state venue laws to resolve the federal corporate venue issue will produce uniform and fair procedures for venue in hitigation involving corporate defendants in both state and federal courts. ${ }^{158}$ The traditional argument that variation between state and federal law should be encouraged because of the benefits of legal experimentation ${ }^{159}$ has little application in this situation. All of the states have demonstrated an unwillingness to experiment witl corporate venue law, and there is no persuasive reason why federal law should differ from state law in this area. ${ }^{160}$

155. See supra note 141.

156. See supra note 154.

157. The Davis court did in fact consider state law when it spoke of the statewide effect of a certificate of incorporation. 549 F.2d at 323 . However, it failed to consider other state law issues-particularly the issue of limited venue-more directly related to the issue before it.

158. Any state could, of course, change its venue law to provide for statewide venue against corporate defendants, thus eliminating the uniformity that now exists in the law. However, in view of the fact that the law has remained uniform since well before 1948 , such a change is unlikely.

At the same time, while Congress could easily correct the defects in $\S 1391(\mathrm{c})$, it cannot be expected to do so. See G. GiLMORE, The AGes of AMERICAN LAw 95-96 (1977) ("On the federal level it is difficult to the point of impossibility to draw the attention of a crisis-ridden Congress to any area of law reform which, although it may be urgent, has not erupted in political controversy."); Wright, Forword [sic] to LegISLATIVE HISTORY, supra note 61, at iii (the Judicial Code is "the only one we are likely to have for a good many years.").

159. See New State Ice Co. v. Liebmann, 285 U.S. 262, 311 (1932) (Brandeis, J., dissenting) ("It is one of the happy incidents of the federal system that a . . . State inay, if its citizens choose, serve as a laboratory, and try novel social and economic experiments without risk to the rest of the country."). While the independent power of Congress to experiment with federal venue is not disputed, there is no indication that $\S 1391$ (c) represents such an experiment.

160. WRIGHT \& MILLER, supra note 3, states that

There is no reason whatever to suppose that a federal statute apportioning business among the various federal courts is to be construed in the light of state law. Such a construction would lead to confusion and lack of uniformity in a statute that should have one meaning throughont the country and should not be dependent on the vagaries of state laws apportioning the business among the courts of a single state.

Id. $\S 3803$, at 12. Unfortunately, because of the split between Davis and Jacobson, § 1391(c) has more than one ineaning throughout the country. Furthermore, the uniforimity of state law on the subject of corporate venue renders the WRIGHT \& MILLER analysis inapplicable to that issue.

In Taylor v. Titan Midwest Constr. Corp., 474 F. Supp. 145, 147 (N.D. Tex. 1979), the court stated that resort by the federal courts to state law concerning a contractual venue provision would "balkanize venue rules when a uniform rule is patently preferable." The court noted that while under Texas law the provision would not be enforceable, "[t]he result that would obtain under Missouri law is unclear." Id. at n.l. In contrast to the situation faced by the court in Taylor, state law on the subject of corporate venue is both clear and uniform. See supra note 154 and acconipanying text. 
Adoption of the limited venue position will also help to reduce unnecessary federal hitigation. The probable result of statewide federal venue is harassment of corporate defendants. These litigants would be forced to defend suits in remote locations within the boundaries of a state, based only on incorporation or licensure within that state. Some plaimtiffs could be tempted to file claims against corporate defendants in federal court in order to be able to use the possibility of litigation in an inconvenient forum as a threat in settlement negotiations. ${ }^{161}$ Thus, if statewide venue were definitively established as the federal rule of decision, there would be mcreased use of the federal courts, adding to the well-known docket pressures these courts face.

Another disadvantage of the statewide venue position is the possibility that it will result in unnecessary increases in corporate expenditures for legal services. A busmess operating under statewide venue is faced with two unattractive choices. It can make arrangements in advance to have counsel retamed in every district in the state, even though such counsel may never be needed. Such a choice is obviously not feasible for a small corporation with limited resources that does business in only a limited area of the state. Alternatively, the firm can look for counsel at the time suit is filed. This choice is also problematic, however, because the firm may have to choose counsel under pressure, in a market for legal services with which it is unfamihar. Either alternative is thus potentially economically inefficient, and a venue regine which forces businesses into choosmg between them should be avoided.

Fimally, as a matter of construction, an awkward readimg of the statute is required if the "doing busmess" clause is read to apply to simgle districts, while the incorporation and hicensure clauses are, pursuant to Davis, read to apply to several districts. The effect of this awkward reading would be an unjustifiable burden upon busmesses complying with state corporation laws, while providing a correspondmgly unjustifiable benefit to "unauthorized" corporations. ${ }^{162}$ Thus, in the absence of a superseding provision of the venue statute, ${ }^{163}$ section 1391(c) should be read to allow suits to be brought only in a federal judicial district in which the corporate defendant either is officially recognized by the state (under the imcorporation or hicensure clauses) ${ }^{164}$ or

161. Cf. Foster, Place of Trial, 44 Harv. L. REv. 41, 43 (1930) ("[T]hen as now there was a temptation to choose the most inconvenient place for the defendant whether or not it was convenient for the plaintiff.")

162. See supra note 146 and accompanying text.

163. E.g., § 1391(a) (1976).

164. See, e.g., [111.] Bus. Corp. Act. \& 11, ILL. ANN. STAT. ch. 32, § 157.11 (Smith-Hurd 1970), which requires that an Illinois corporation inaintain a registered office in the state, and that its address be stated in the articles of incorporation. 
is doing business.

\section{B. Possible Objections to the Proposed Standard}

At first glance, the proposal that courts consider the uniformity of state venue laws when construing section 1391(c) seems susceptible to two nnajor objections. The first is that state law cannot constitutionally control federal venue. The second is that the proposal seems inconsistent with the Erie doctrine. Neither objection, however, withstands closer scrutiny.

Since the Constitution gives Congress the power to allocate judicial business anong the federal courts, ${ }^{165}$ it is settled that state law cannot control federal venue. ${ }^{166}$ Some commentators have gone so far as to say that federal venue is "wholly a matter of federal law and state venue provisions are mapplicable."167 The federal court decisions on the subject, however, actually hold only that state law is not conclusive, and that the ultimate determination of issues relating to federal venue is the responsibility of the federal courts. ${ }^{168}$ Furtherunore, these decisions have been concerned only with the status of an individual state's venue law vis-a-vis federal venue law. They thus do not address the proposal advanced by this Comment, which is based on the fact that the laws of the states are almost unanimously at odds with the statewide venue position adopted by the Fifth Circuit in Davis.

To a certam extent, state law already controls the resolution of some issues under section 1391(c). Whether a business is incorporated or licensed to do business im a given federal district is an issue which depends on the provisions of the law of the state issuing the license or the certificate of incorporation. In addition, several courts have considered the statewide effect of a certificate of imcorporation-another matter of state law-in deciding the propriety of statewide venue. ${ }^{169}$ If the corporation laws of the states are to be considered in the resolution of federal venue issues, all relevant aspects of those laws should be considered. Consideration of the state law in this manner is particularly appropriate in the situation addressed by this Comment, since no one state's law would be allowed to determine the issue. Thus, recognition of the consistency of state venue law by the federal courts would not

165. U.S. CoNST. art. III, \& I.

166. Munter v. Weil Corset Co., 261 U.S. 276, 278 (1923); Moore's Federal Practice, supra note 77, \ 0.140 [1.-3-1], at 1313 (venue in the federal courts is statutory and procedural; thus, neither the Rules of Decision Act nor Erie applies).

167. WRIGHT \& MILLER, supra note $3, \S 3803$, at 10.

168. See, eg., Cochrane v. Iowa Beef Processors, 596 F.2d 254, 260 (8th Cir. 1979); Miller v. Davis, 507 F.2d 308, 316 (6th Cir. 1974).

169. See, e.g., Fuller \& Dees Mktg. Group v. Outstanding Am. High School Students, 335 F. Supp. 913,914 (M.D. Ala. 1972). 
constitute an abdication of their power to determine federal venue issues.

The Erie doctrine ${ }^{170}$ teaches that when federal procedural law conflicts with the procedural law of any given state, federal procedural law controls. ${ }^{171}$ This Comment does not, however, propose that the venue law of any particular state supersede federal venue law. It inerely suggests that the almost total rejection by state venue laws of a statewide theory of corporate venue should be considered in the formulation of federal venue law. Thus, the proposal does not conflict with the Erie doctrine.

The proposal suggested by this Cominent would not be justiflable in the face of either unambiguous statutory language or clear evidence of contrary congressional intent; if present, such factors would be controlling. ${ }^{172}$ However, as this Comment has shown, ${ }^{173}$ the language of section 1391(c) can be construed as supporting either a limited or a statewide theory of federal venue for corporate defendants, and congressional imtent in enacting the statute is unclear. The lack of guidance from either of these controlling sources creates the need to examme other factors. Nor would the proposal be justiflable if it could be shown that the venue statutes of the various states had been passed in atteinpts to frustrate a national policy in favor of statewide venue or in some manner to restrict access to federal courts. There is no evidence, however, that this was the case. The state venue statutes apply only to state courts, and do not attempt to govern federal venue. Furtherinore, many of thein existed basically in their present forin while federal venue law was still in its formative stages. ${ }^{174}$ Their only purpose seems to be to give corporate defendants the rights that other defendants have to litigate in forums having some connection with either the parties to, or the subject matter of, the hitigation.

\section{CONCLUSION}

Venue rules balance a plaintiff's interest in litigating in the forum of his choice against a defendant's interest in defending the lawsuit in a convenient forum. Under current law, these conflicting interests are resolved by the requirement that litigation occur in a location to which one or more of the parties, or the litigation itself, has some relationship.

170. See Erie R.R. v. Tompkins, 304 U.S. 64 (1938).

171. See Byrd v. Blue Ridge Rural Elec. Coop., 356 U.S. 525 (1958).

172. It is, of course, fully within Congress' power to enact a statewide federal venue statute to apply to multidistrict as well as single district states. However, simce it is unlikely that Congress intended § 1391 (c) to be such a statute, it is necessary to look beyond federal law to resolve the issue.

173. See supra note 123 and accompanying text.

174. See, e.g., N.Y. CIv. PraC. ACt. ANN. § 182 (Gilbert-Bliss 1920). 
Allowing a suit to be heard in any judicial district of the state of incorporation is offensive to this doctrine. Since it is not clear that Congress in enacting section 1391(c) intended to make such a drastic change in the traditional venue rules, statewide venue should be rejected. Instead, future decisions should view the unanimity of result reached under the aggregate of state venue laws as an implicit national policy in favor of limited venue.

Frank D. Kortum*

* Third-year student, Boalt Hall School of Law, University of California, Berkeley. 